\title{
Toxicity and Lethality Evaluations of Koordersiodendron pinnatum Leaves Methanolic Extract in DDY Mice
}

Sofna Dewita Sari Banjarnahor, Indah Dwiatmi Dewijanti, Marissa Angelina, Sofa Fajriah

Research Center for Chemistry, Indonesian Institute of Sciences (LIPI), Banten, Indonesia

\section{ABSTRACT}

The study of toxic features of Koordersiodendron pinnatum is vital for further studies of its pharmacological activities. Acute toxicity test was done on methanolic extracts of $K$. pinnatum in DDY mice. Animals were grouped into five: Group 1 was given $1 \mathrm{~mL}$ solution of $2.5 \%$ Tween 80 in a single oral dose; the remaining groups were orally given a single dose of $2,4,8$ and $16 \mathrm{~g} / \mathrm{kg}$ of $K$. pinnatum, respectively. Toxic effects of the extract were evaluated on the basis of behavioral observations in the form of locomotor activity; curiosity; defecation; urination and also animal mortality. Observations were carried out for 14 days. No significant changes on body weight, and behavioural activities were recorded. Mortality was recorded up to $2 \%$ of the male group, and no mortality within the female group. The extract is practically non toxic for both male and female $\left(\mathrm{LD}_{50}>15 \mathrm{~g} / \mathrm{kg}\right)$.

Keywords: Koordersiodendron pinnatum, Acute oral toxicity, $L D_{50}$

\section{INTRODUCTION}

Koordersiodendron pinnatum tree, member of the family Anarcadiaceae, is naturally grown in the tropical areas. The habitat is scattered in some areas such as the Philippines, Malaysia, and Indonesia [1]. In Indonesia, $K$. pinnatum, which is locally known as bugis or wood siuri, grows naturally in the area of Northern Papua, Maluku and Sulawesi. Index Value (IVI) is important rate of this plant is the highest in the Group of trees, poles and stakes that are found in the area of Rawa Aopa National Park in Southeast Sulawesi. The tree is still underutilized, therefore its existence in the ecosystem is still guaranteed [2]. Whilst in Philippines, this plant is categorized as vulnerable spec [3].

Information regarding the utilization of these plants either empirically or scientifically is still very limited. According to the Philippine medicinal plants, amugis (local name for $K$. pinnatum) is used as a remedy for chronic wounds, also on bruises and sprains, and the decoction from the bark is used as a gargle for sore throat. In India, the plant is used as a lotion for impetigo [4]. Other studies have also found the antibacterial and antioxidant effects of ethanol extracts of

${ }^{*}$ Corresponding author:

Sofna Dewita Sari Banjarnahor

Research Center for Chemistry, Indonesian Institute of Sciences

Kawasan PUSPIPTEK, Tangerang Selatan, Banten 15314, Indonesia

E-mail address: sofna99@gmail.com this plant against gram-positive and gram-negative bacteria $[5,6]$.

Toxicity is the concomitant of interactional activity between pollutants and host cells. This toxic interrelation may vary depending on the physical properties of the toxicants and cell membrane, as it may express either on or inside the cellular milieu, or at the extracellular matrix. Evidence of the toxic effects can exist at any stage prior to the binding with major organs like kidneys and liver. Thus, in plant-derived bioactive drugs development, investigation on potential toxicity of a substance is critical. Because acquaintance to chemical compound despite being natural are not always safe and can create detrimental response in human's body [7].

Although medicinal plants dates back to nature but it is a foreign object to the human body. Therefore, toxicity study of a plant or a new compound is absolutely indispensable as the basis for the development of new drugs. This study aim to evaluate the potential toxicity of the methanolic extract of $K$. pinnatum leaves

\section{How to cite:}

Banjarnahor SDS, Dewijanti ID, Angelina M, Fajriah S (2016)

Toxicity and Lethality Evaluations of Koordersiodendron pinnatum Leaves Methanolic Extract in DDY Mice. J. Trop. Life Science 6 (3): $190-195$. 


\section{MATERIALS AND METHODS}

\section{Ethical issue}

The experimental procedures were performed upon approval from the Ethical Committee (Medical Faculty, University of Indonesia) number No.44/UN2.F1/ ETIK/2014.

\section{Plant sample}

Koordersiodendron pinnatum (Blanco) Merr. leaves were collected from Mekongga forest, southeastern part of Sulawesi in March 2012. The voucher specimen has been deposited in the Herbarium Bogorienses, Research Centre for Biology, Indonesian Institute of Sciences.

\section{Methanol extract preparation}

Fresh leaves were dried and cut into small pieces $(2,369 \mathrm{~g})$. The sample was macerated successfully using n-hexane and methanol at room temperature three times before evaporated using vacuum technique to obtain thick extract. The extract was stored at room temperature before the toxicological studies were performed.

\section{Evaluation of the neurobehavioral \\ Open field assay}

This assay was used to assess the spontaneous locomotive, exploratory and curiosity activities of both male and female mice. The apparatus was made of a circular board with a diameter of $50 \mathrm{~cm}$ and placed at $50 \mathrm{~cm}$ height from the bottom. Line was drawn on the board to form two equally experimental areas. A small hole located at the center of the board was added to evaluate the curiosity activities.

Animals were placed individually in the field and number of head dipping, head elevation, hind limb elevation, sniffing, grooming, rearing, squares crossed, gait abnormality, urination and fecal boluses were measured for two minutes. Tests were performed within one hour prior to and after the treatment, and shortly before the autopsy (on day 14) $[8,9]$.

\section{Grip strength test}

Evaluation of spontaneous motor movements was conducted through grip strength test method [10]. Animals were placed on a horizontal wire at a height of 50 $\mathrm{cm}$ from the bottom. Latency to fall is documented to evaluate the muscle strength of forelimbs and hind limbs. This observation was carried out as described [11].
Table 1. Phytochemical screening of $K$. pinnatum methanol extract

\begin{tabular}{|c|c|c|}
\hline No. & Compound & $(+) /(-)$ \\
\hline 1. & Alkaloid & $(+)$ \\
\hline 2. & Flavonoid & $(+)$ \\
\hline 3. & Terpene & $(+)$ \\
\hline 4. & Saponin & $(-)$ \\
\hline
\end{tabular}

Note: (-) negative; (+) positive

\section{Acute oral toxicity and lethal dosage ${ }_{50}\left(L D_{50}\right)$ determi- nation}

The acute oral toxicity of $K$. pinnatum methanol extract was examined in mice as specified to the procedure outlined by the Organization for Economic Cooperation and Development [12]. The experiment was conducted on 50 healthy DDY mice of both sexes weighting between $25-30 \mathrm{~g}$ aged 8 - 10 weeks obtained from the Laboratorium of Non-Ruminancy Veterinary Faculty, Bogor Agricultural Institute. The animals were subjected to acclimatization for a week before used, and fed with standard growers mash feeds and water ad libitum. Animals were randomly distributed into five groups, i.e., four treated groups and one control group of opposite sex.

Prior to the actual study, a preliminary test on a small group of mice was carried to determine dose range. A single dose of $2,4,8$, and $16 \mathrm{~g} / \mathrm{kg}$ of $K$. pinnatum were administered orally. Before handling, mice were kept fasted overnight to remove feed from digestive tract. All mice were thoroughly examined after suspension administration immediately for the emergence of any toxic signs and once daily afterward for 14 days of treatment period to document any delayed toxic effects. Survival, feed consumption, and body weight were monitored. On day 14, surviving mice were sacrificed. Gross necropsy was conducted, and organs were weighed. The lethal dosage ${ }_{50}\left(\mathrm{LD}_{50}\right)$ of the extract was calculated using the arithmetic method of Reed and Muench [13].

\section{Statistical analysis}

Results are demonstrated as the mean \pm SD. Behavioral observations, body weight, organ weight, and food intake were tested by conducting One-Way ANOVA using SPSS 17 statistical software.

\section{RESULTS AND DISCUSSION \\ Extraction and phytochemical screening}

An amount of 2,369 $\mathrm{g}$ of the dried leaves of $K$. pinnatum yielded $304 \mathrm{~g}$ of the crude extract equivalent to $12.83 \%$. The extract is a dark brown thick oily subs- 


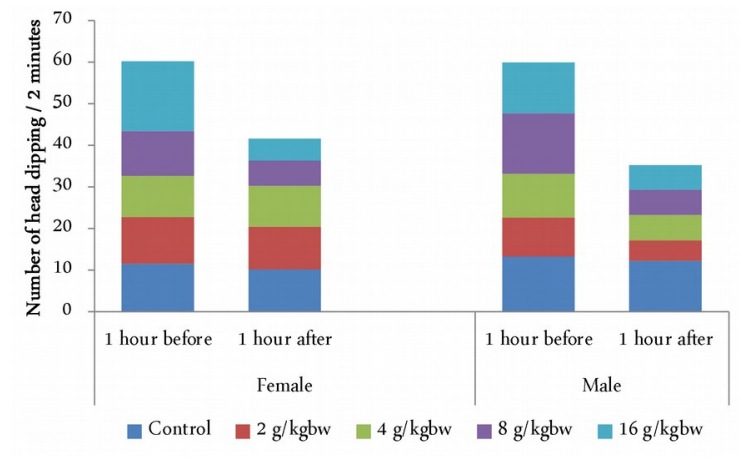

Figure 1. Effect of $K$. pinnatum methanol extract on head dipping activity in female and male mice

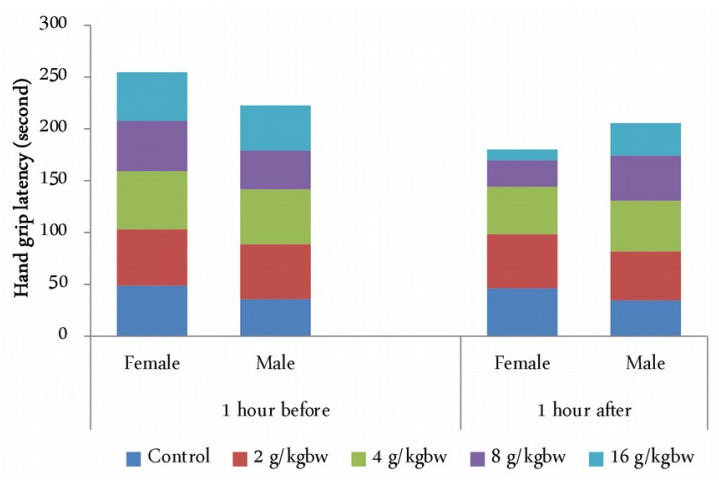

Figure 2. Effect of $K$. pinnatum methanol extract on grip strenght in female and male mice

stance. Stored at room temperature in a bottle container. Phytochemical screening results showed the extract positive contained flavonoid, alkaloid, and terpene but negative for saponin (Table 1).

\section{Neurobehavioural assessment}

During a two-minute period of open field test, the extract did not significantly reduce the number of head dipping in the control group, but did significantly reduce the head dipping activity in the treatment groups at any dose tested $(\mathrm{p}<0.05)$. Similar patterns were found in both sexes as seen in Figure 1.

The impact of the extract on grip strength in mice is shown in Figure 2. Following extract administration, latency time was significantly reduced in female mice that received $8 \mathrm{~g} / \mathrm{kg}$ and $16 \mathrm{~g} / \mathrm{kg}$ extract. Conversely, handgrip latency in other groups shows no significant changes. Similarly, handgrip latency in male mice was not significantly decreased by the treatment. These indicate a negative effect either the extract or the handling on exploratory behavior and curiosity in all animals given the $K$. pinnatum extract.

Emotions and locomotors activities were decreased in most of the test animals after administration of the

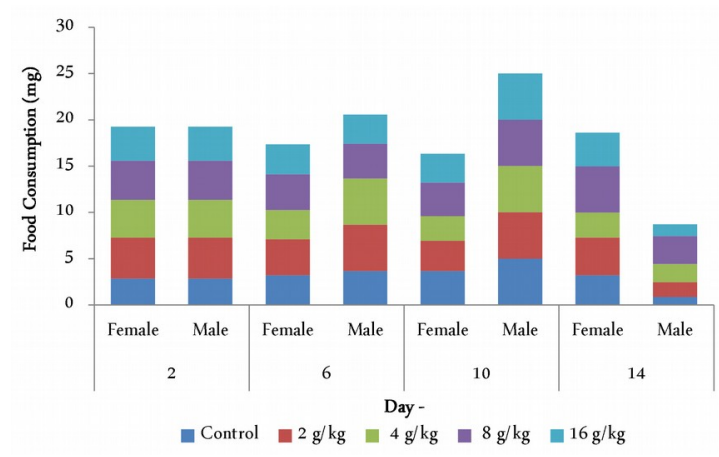

Figure 3. Effect of $K$. pinnatum methanol extract on food consumption in 14 days to female and male mice

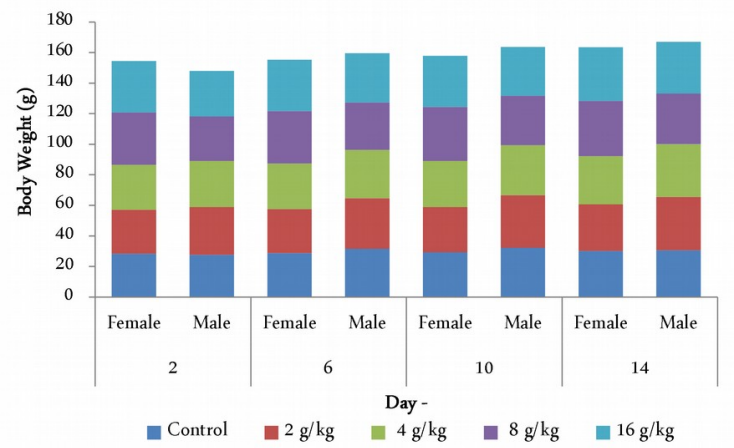

Figure 4. Effect of $K$ pinnatum methanol extract on body weight changes during 14 days to female and male mice

extract. However, this decrease was within normal limits, this is due to the presence of stress factors caused by the treatments. These factors include the oral procedure, the presence of the toxic effects of the active substance, and the physical properties of the test preparation or carrier. In general, mice are experimental animals that are susceptible to stress caused by the physical treatment, and this is shown in the form of changes in behavior, urination and fecal boluses (data not shown) [14].

The aim of this test is to evaluate the animals fore and/or hind limb strength. This assay can be used to assess neurobehavioral effect of a substance as well as to investigate effect of distinct treatment in mouse models of neuromuscular diseases; decreases in grip strength have been interpreted as evidence of decreased muscle strength [15]. It appears that the methanolic extract of $K$. pinnatum has no toxic effect on neurobehavioral system of both male and female mice.

\section{Acute oral toxicity and $L D_{50}$ determination}

The potential toxicity effect of the methanolic extract of $K$. pinnatum on the manifestation and behavioral motif mice are shown in Table 2. Alterations in 


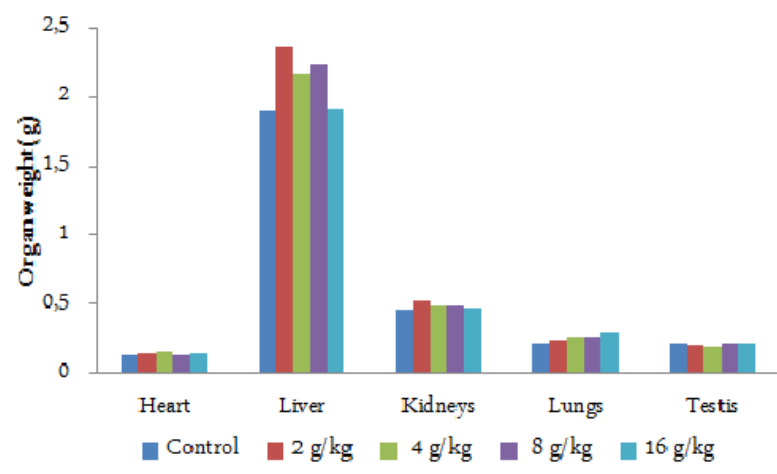

(a)

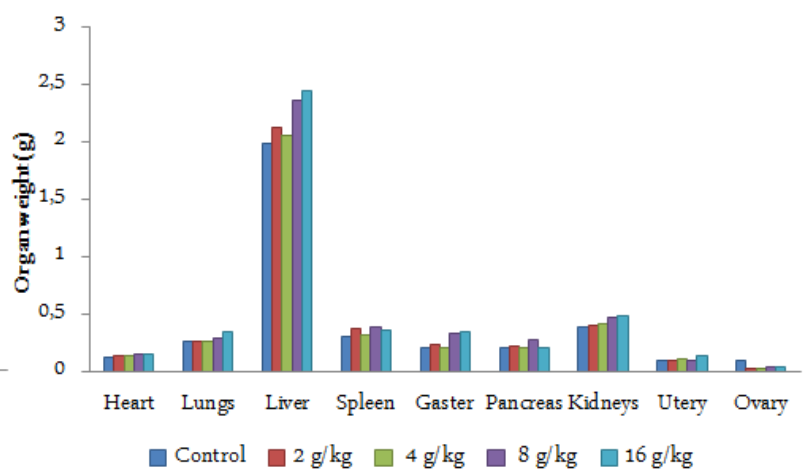

(b)

Figure 5. Effect of $K$. pinnatum methanol extract on organs weight in male (a) and female (b) mice

Table 2. Means of general appearances and behavioral observations

\begin{tabular}{|c|c|c|c|c|c|c|c|c|c|c|}
\hline \multirow[t]{2}{*}{ Observation } & \multicolumn{5}{|c|}{ Male } & \multicolumn{5}{|c|}{ Female } \\
\hline & 1 & 2 & 3 & 4 & 5 & 1 & 2 & 3 & 4 & 5 \\
\hline Skin and fur & $\mathrm{N}$ & $\mathrm{N}$ & $\mathrm{N}$ & $\mathrm{N}$ & $\mathrm{N}$ & $\mathrm{N}$ & $\mathrm{N}$ & $\mathrm{N}$ & $\mathrm{N}$ & $\mathrm{N}$ \\
\hline Eyes & $\mathrm{N}$ & $\mathrm{N}$ & $\mathrm{N}$ & $\mathrm{N}$ & $\mathrm{N}$ & $\mathrm{N}$ & $\mathrm{N}$ & $\mathrm{N}$ & $\mathrm{N}$ & $\mathrm{N}$ \\
\hline Mucous membrane & $\mathrm{N}$ & $\mathrm{N}$ & $\mathrm{N}$ & $\mathrm{N}$ & $\mathrm{N}$ & $\mathrm{N}$ & $\mathrm{N}$ & $\mathrm{N}$ & $\mathrm{N}$ & $\mathrm{N}$ \\
\hline Behavioral patterns & $\mathrm{N}$ & $\mathrm{N}$ & $\mathrm{N}$ & $\mathrm{N}$ & $\mathrm{N}$ & $\mathrm{N}$ & $\mathrm{N}$ & $\mathrm{N}$ & $\mathrm{N}$ & $\mathrm{N}$ \\
\hline Salivation & $\mathrm{N}$ & $\mathrm{N}$ & $\mathrm{N}$ & $\mathrm{N}$ & $\mathrm{N}$ & $\mathrm{N}$ & $\mathrm{N}$ & $\mathrm{N}$ & $\mathrm{N}$ & $\mathrm{N}$ \\
\hline Lethargy & $\mathrm{N}$ & $\mathrm{N}$ & $\mathrm{N}$ & $\mathrm{N}$ & $\mathrm{N}$ & $\mathrm{N}$ & $\mathrm{N}$ & $\mathrm{N}$ & $\mathrm{N}$ & $\mathrm{N}$ \\
\hline Sleep & $\mathrm{N}$ & $\mathrm{N}$ & $\mathrm{N}$ & $\mathrm{N}$ & $\mathrm{N}$ & $\mathrm{N}$ & $\mathrm{N}$ & $\mathrm{N}$ & $\mathrm{N}$ & $\mathrm{N}$ \\
\hline
\end{tabular}

Note: The observations expressed in more than half of the group; $\mathrm{N}=$ Normal

Table 3. Effect of $K$. pinnatum methanol extract on organ-to-body-weight index (\%) in male mice

\begin{tabular}{|c|c|c|c|c|c|c|c|c|}
\hline \multirow{2}{*}{ No. } & \multirow{2}{*}{ Group } & \multirow{2}{*}{ Body Weight (g) } & \multicolumn{6}{|c|}{ Organ-to-body-weight (\%) } \\
\hline & & & Heart & Lungs & Liver & Kidneys & Spleen & Testis \\
\hline 1. & Control & 30.56 & $0.42 \pm 0.08$ & $0.69 \pm 0.11$ & $6.23 \pm 0.9$ & $1.52 \pm 0.18$ & $0.94 \pm 0.33$ & $0.72 \pm 0.08$ \\
\hline 2. & $2 \mathrm{~g} / \mathrm{kg}$ & 34.87 & $0.41 \pm 0.09$ & $0.70 \pm 0.11$ & $6.78 \pm 1.06$ & $1.36 \pm 0.46$ & $0.95 \pm 0.29$ & $0.68 \pm 0.18$ \\
\hline 3. & $4 \mathrm{~g} / \mathrm{kg}$ & 34.57 & $0.43 \pm 0.08$ & $0.78 \pm 0.15$ & $6.24 \pm 0.88$ & $1.39 \pm 0.2$ & $0.93 \pm 0.39$ & $0.55 \pm 0.06$ \\
\hline 4. & $8 \mathrm{~g} / \mathrm{kg}$ & 33.01 & $0.4 \pm 0.05$ & $0.83 \pm 0.18$ & $6.76 \pm 0.83$ & $1.46 \pm 0.11$ & $1.03 \pm 0.43$ & $0.66 \pm 0.12$ \\
\hline 5. & $16 \mathrm{~g} / \mathrm{kg}$ & 33.86 & $0.41 \pm 0.08$ & $0.85 \pm 0.4$ & $5.45 \pm 1.73$ & $1.4 \pm 0.18$ & $0.87 \pm 0.31$ & $0.62 \pm 0.11$ \\
\hline
\end{tabular}

Table 4. Effect of $K$. pinnatum methanol extract on organ-to-body-weight index (\%) in female mice

\begin{tabular}{ccccccccc}
\hline \multirow{2}{*}{ No. } & Group & Body Weight $(g)$ & \multicolumn{5}{c}{ Organ-to-body-weight $(\%)$} \\
\cline { 4 - 8 } & & & Heart & Lungs & Liver & Kidneys & Spleen & Ovarium \\
\hline 1 & Control & 30.02 & $0.4 \pm 0.05$ & $0.86 \pm 0.11$ & $6.62 \pm 1.35$ & $1.26 \pm 0.2$ & $0.99 \pm 0.28$ & $0.09 \pm 0.03$ \\
2 & $2 \mathrm{~g} / \mathrm{kg}$ & 30.56 & $0.46 \pm 0.09$ & $0.876 \pm 0.09$ & $6.93 \pm 0.87$ & $1.314 \pm 0.11$ & $0.97 \pm 0.27$ & $0.093 \pm 0.03$ \\
3 & $4 \mathrm{~g} / \mathrm{kg}$ & 31.44 & $0.42 \pm 0.09$ & $0.82 \pm 0.21$ & $6.57 \pm 1.17$ & $1.34 \pm 0.29$ & $1.04 \pm 0.42$ & $0.103 \pm 0.04$ \\
4 & $8 \mathrm{~g} / \mathrm{kg}$ & 36.16 & $0.416 \pm 0.1$ & $0.8 \pm 0.14$ & $6.52 \pm 0.73$ & $1.31 \pm 0.14$ & $1.09 \pm 0.26$ & $0.106 \pm 0.05$ \\
5 & $16 \mathrm{~g} / \mathrm{kg}$ & 35.23 & $0.44 \pm 0.06$ & $1 \pm 0.18$ & $6.94 \pm 1.25$ & $1.36 \pm 0.27$ & $1.03 \pm 0.38$ & $0.11 \pm 0.03$ \\
\hline
\end{tabular}

Note: Organ body index $=($ organ weight $\times 100)$ /body weight; values are mean $\pm \mathrm{SD}, \mathrm{p}<0.05$ 
the amount of feed consumption and also body weight during the treatment is one of quantitative criteria for toxic effects. Mean amounts of food intake by female and male mice in the treated groups and in the control group are shown in Figure 3. Both sexes showed no significant changes on the amount of food and fluid consumption (data not shown).

Monitoring of weight showed no significant changes $(p>0.005)$ as seen in Figure 4. The body weight of the female mice given the highest dose during the first few days of treatment showed a significant decrease (Figure 4) $(\mathrm{p}<0.05)$, this indicates that the extract might have potential on metabolism with increasing dose. Whereas, the body weight in male group show no significant changes during the treatment period.

However, it could be argued that these fluctuations may not be toxic, as they were not corroborated with other findings (organ weight, gross necropsy). None of the animals expressed any behavioral changes, and no changes, or toxic signs or symptoms were noticed. Accordingly, it seems likely that methanolic extracts of $K$. pinnatum administered by the oral route are not toxic at the studied doses.

LD50 calculation results, based on mortality data (data not shown), showed that the LD50 value in the group of male and female is apparent; this means that the methanol extract of $K$. pinnatum is practically nontoxic [16].

In addition, measurement of organ-to-body-weight index is also the frontline markers of potential toxicity of a substance, because organs such as the heart, lungs, liver, kidney, and spleen are strongly influenced by the presence of metabolites of toxicant [17]. Measurement of relative organ weight in both the control and the treatment mice are presented in Table 4 and Table 5 . Figure 5 and Figure 6 displayed the absolute organ weight of male and female mice, respectively. Based on the data obtained, no significant weight changes ( $p>$ 0.05) were found from the vital organs.

\section{CONCLUSION}

Our results indicate that the methanolic extract of $K$. pinnatum is practically safe to be consumed through oral administration. Further biochemical studies to furnish more information relating to the toxicity are recommended.

\section{ACKNOWLEDGMENT}

This study was sponsored by LIPI Competitive Research Grant 2012-2014. Authors are thankful to
Prof. Dr. Sci. Muhammad Hanafi and Puspa DN Lotulung M.Eng for the support and suggestion.

\section{REFERENCES}

1. Asian Plant (2016) Koordersiodendron pinnatum. http://www.asianplant.net/Anacardiaceae/Koordersiodend ron_pinnatum.htm. Accessed: June 2016

2. Putri IASLP, Allo MK (2004) Degradasi Keanekaragaman Hayati Taman Nasional Rawa AOPA Watumohai. Jurnal Penelitian Hutan dan Konservasi Alam, VI (2): 169-194.

3. Department of Environment and Natural Resources (2007) Establishing the national list of threatened Philippine plants and their categories, and the list of other wildlife species. Department of Environment and Natural Resources Administrative Order No. 2007-01. http://server2.denr.gov.ph/. Accessed: June 2016.

4. De Tavera THP (1901) The Medicinal Plants of the Philippines. Philadelphia, P. Blakiston's Son \& Co.

5. Praptiwi, Harapini M (2004) Pengujian antibakteri dan antioksidan ekstrak kulit batang siuri (Koordersiodendron pinnatum (Blanco) Merr.). Majalah Farmasi Indonesia. 15(3): 151-157.

6. Fajriah S, Darmawan A, Hanafi M (2012) Potential Antioxidant Constituent from Koordersiodendron pinnatum Leaves. In proceedings of International Conference on Biotechnology: 13-14 November 2012; Bogor. Research Center for Biotechnology, Indonesian Institute of Sciences. 395-399.

7. Asante-Duah K (2002) Public Health Risk Assessment for Human Exposure to Chemicals. 1st Edition. New York, Springer Netherlands

8. Roth AK, Katz RJ (1979) Stress, Behavioral Arousal, and Open Field Activity A Reexamination of Emotionality in the Rat. Neuroscience \& Biobehavioral Reviews. 3:247263.

9. Denenberg VH (1969) Open-field behavior in the rat: What does it mean?. Annals of the New York Academy of Sciences. 159:852-9.

10. Suárez A, Echandi MM, Ulate G, Cicció JF (2003) Pharmacological activity of the essential oil of Satureja viminea (Lamiaceae). Rev. Biol. Trop. 51(1): 247-52.

11. Barclay LL, Gibson GE, Blass JP (1981) The string test: an early behavioral change in thiamine deficiency. Pharmacol Biochem Behav. 14:153-7.

12. OECD (2001) Guidelines for acute toxicity of chemicals No. 420.http://www.oecd.org/. Accessed: June 2016

13. Al-Sultan SI, Hussein YA (2006) Acute Toxicity of Euphorbia heliscopia in Rats. Pakistan Journal of Nutrition. 5 (2): 135-40.

14. Balcombe JP, Barnard ND, Sandusky C (2004) Laboratory Routines Cause Animal Stress. Contemp. Top. Lab. Anim. 
Sci. 43(6): 42-51.

15. Meyer OA, Tilson HA, Bird WC, Riley MT (1979) A method for the routine assessment of fore- and hind limb grip strength of rats and mice. Neurobehav Toxicol. 1:233-6.

16. Loomis TA (1978) Essential of toxicology. 3rd ed.
Philadelpia, Lea \& Febiger.

17. Dybing E, Doe J, Groten J et al (2002) Hazard characterization of chemicals in food and diet: dose response, mechanism and extrapolation issues. Food Chem. Toxicol. 42:237-82. 